COLLOQUIA THEOLOGICA OTTONIANA 2/2017, s. 255-258

DOI: $10.18276 /$ cto.2017.2-15

\title{
WYSTAWA MADE IN ROMA AND AQUILEIA
}

\author{
Cezary Korzec ${ }^{*}$ \\ Wydział Teologiczny Uniwersytetu Szczecińskiego
}

Otwarta w sobotę 11 lutego 2017 roku w pałacu Meizlik w Akwilei wystawa jest wydarzeniem kulturalnym mającym istotny aspekt naukowy i popularyzujący badania historyczne. Wydarzenie zostało przygotowane i szeroko rozreklamowane przez Fondazione Aquileia we współpracy z innymi instutucjami: Assesorato Alla Crescita Culturale di Roma Capitale, Sovrintendenza Capitolina ai Beni Culturali - Mercati di Traiano Museo dei Fori Imperiali, Polo Museale del Friuli Venezia Giulia, urząd miejski Akwielei i Associazione Nazionale per Aquileia. Partnerami w realizacji projektu były instytucja finansowa Banca di Credito Cooperativo di Fiumicello e Aiello i przedsiębiorstwa: Trieste Airport, Confindustria e Palmanova Outlet Village. Wystawa została zorganizowana jako przedłużenie rzymskiej wystawy wyeksponowanej w Forum Trajana zatytułowanej Made in Roma. Kuratorami wystawy akwilejskiej byli Annalisa Giovannini, realizatorka wielu historycznych ekspozycji na terenie miasta, Marta Novello, dyrektorka miejscowego muzeum archeologicznego i Cristiano Tiussi, przewodniczący Fondazione Aquileia.

Umiejscowienie wystawy w Akwilei ma swoje racje z powodu bogatej historii miasta. Założone w roku 181 przed Chr., stało się niecałe sto lat później stolicą X regionu (Venetia et Histria) cesarstwa rzymskiego. Poprzez swoje położenie geograficzne - pomiędzy wybrzeżem Morza Śródziemnego a pasmem

* Ks. dr hab. Cezary Korzec, prof. US - prezbiter diecezji archidiecezji szczecińskokamieńskiej. Profesor nadzwyczajny w Katedrze Egzegezy i Teologii Biblijnej Wydziału Teologicznego Uniwersytetu Szczecińskiego. Zainteresowania badawcze: teologia i archeologia biblijna. E-mail: cezary.korzec@usz.edu.pl. 
Alp - stanowiło doskonały punkt w łańcuchu produkcji, importu i eksportu. Przylegający do miasta port rzeczny połączony systemem kanałów z Morzem Śródziemnym i najbliższą okolicą sam w sobie stanowił mikroświat więzi ekonomicznych. Jednocześnie stwarzał okazję do ekspansji ekonomicznej i kulturowej wewnątrz regionu oraz poza nim w kierunku północnym do obszarów pozaalpejskich. Nie mniej interesująca i bogata jest historia miasta w wiekach średnich. Także współcześnie dzięki zakrojonym na szeroką skalę pracom archeologicznym na terenie rzymskiej Akwilei i renowacjom chrześcijańskich bazylik miasto stało się ważnym centrum turystycznym położnym pomiędzy Wenecją i Triestem.

Celem wystawy stało się wyeksponowanie i docenienie marek i znaków związanych z produkcją i posiadaniem przedmiotów w przeszłości. Wystawie towarzyszyło fundamentalne przekonanie, że produkty pochodzące $\mathrm{z}$ regionu Friuli-Wenecja Julijska, którego Akwileja przez dhugie wieki była centrum administracyjnym, kulturowym i ekonomicznym, mają wysoką jakość, czego korzeni można doszukać się w trwającej dwa tysiące lat produkcji mającej swój początek w epoce imperium rzymskiego.

W przestrzeni wystawowej zostało zgromadzonych i zaprezentowanych ponad 300 obiektów muzealnych pochodzących ze zbiorów Muzeum Archeologicznego w Akwilei i Mercati di Traianodi w Rzymie. Na uwagę zasługują bardzo cenne przedmioty przekazane $\mathrm{w}$ depozyt od instytucji zagranicznych, jak na przykład Römisch-Germanisches Museum der Stadt w Kolonii (Niemcy) czy Arheološki muzej w Splicie (Chorwacja). Zgromadzone przedmioty w większości były już udostępnione dla zwiedzających, czy to formie stałych ekspozycji muzealnych w Akwilei i Rzymie, czy też w postaci okresowych wystaw organizowanych przez zainteresowane instytucje.

$\mathrm{Na}$ liście wystawienniczej znalazły się: brązowa obręcz niewolnika, przedmioty ze szkła, lampki, ozdoby, amfory, narzędzia medyczne i wiele innych obiektów będących w codziennym użytku starożytnych mieszkańców obu miast. Eksponaty charakteryzuje obecność różnorakich znaków przynależności, jak marki, stemple, godła miasta, „logo” właściciela czy podpisy. Są one świadectwem rozwijającej się w czasie relacji producenta, sprzedawcy i nabywcy. Jednocześnie jest to relacja pomiędzy przedmiotem i każdą wspomnianych kategorii osób. O tej sieci relacji sprzed wieków opowiada wystawa. Producent „wyciskający” swój znak, często własne imię, na przedmiocie, produkcie swoje pracy, dokonuje aktu komunikacji, który daje gwarancję określonej jakości produktu dla osoby, która go zakupi. Kupiec szukający towarów do zbycia, ale 
i nabywca, ostatni w łańcuchu osób, nabywając produkt, dokonują gestu zaufania w oparciu o wyciśnięty na nim znak. Ten gest w wielu wypadkach skutkuje wyborem, w wyniku którego spośród wielu istniejących na rynku przedmiotów kupuje się ten jeden odróżniający się od pozostałych marką producenta. Istniejący i wystawiony na widok publiczny poprzez wystawę łańcuch gwarancji i wyborów nie jest jednak czymś odległym, przeszłym. Choć zgromadzone obiekty pochodzą ze starożytności, proces ten nie zakończył się z upadkiem starożytnego Rzymu i Akwilei, ale trwa z wieku na wiek aż do dziś, przybierając formę wybujałą, a nie rzadko patologiczną - konsumpcjonizmu. Marki najczęściej są to po prostu nazwiska przedsiębiorców, z upływem czasu stają się coraz liczniejsze. Wskazują na śmiałych mężczyzn i, co ważne, kobiety, którzy w tamtych czasach szukali ciągle nowych i bardziej chłonnych rynków zbytu.

Zwiedzając wystawę, można podziwiać zgromadzone znaki umieszczone na wytworach przemysłu budowniczego i monetach pochodzący z imperium rzymskiego. Znaczną część kolekcji stanowią wyroby, które w przeszłości budowały markę Akwilei: szklane, medyczne, kamieniarskie, lampki oliwne. Nie zabrakło odniesień do „produktów”, które także dziś stają się niezwykle modne, jak tatuaż. Stał się on szczególnie popularny w połowie XIX wieku za sprawą ponownego odkrycia dokonanego przez James Cooka w roku 1769.

Inną ciekawą część wystawy stanowią eksponaty zgromadzone w celu udokumentowania mało dotychczas przebadanego i znanego aspektu przemysłu budowlanego, jakim są przedsiębiorstwa, w których udział miały kobiety. Temat praktycznie nieobecny w źródłach spisanych znajduje swoją dokumentację w postaci pieczęci wyciśniętych na produktach budowlanych, jak cegły czy dachówki. Znaki noszą imiona kobiet znanych w czasach imperialnych, jak Augusta Pompeja Plotina, żona cesarza Trajana, Vibia Sabina, żona Hadriana, czy Annia Galeria Faustina, córka Marka Antoniusza. Na 150 imion zachowanych na przedmiotach z wieku II i III pochodzących z tego sektora przemysłu pięć jest kobiecych. Na uwagę zasługuje Flavia Seia Isauryjska, pochodząca z rodu senatorskiego, która osiągnęła wielki sukces i otrzymała tytuł pierwszej producentki cegieł w swoim rodzie.

Możliwość zapoznania się z przedmiotami „opowiadającymi” o tak mało znanych aspektach życia codziennego w starożytności, jak i współczesności czyni $\mathrm{z}$ wystawy Made in Roma and Aquileia wydarzenie niezwykle ciekawe dla różnych typów odbiorców. Wystawa dokumentuje i popularyzuje wysiłek badawczy archeologów i historyków, ale i wskazuje na obszary jeszcze mało znane i oczekujące 
na swoich odkrywców w przeszłości tej odległej, jak i tej całkiem bliskiej. Z pewnością wartością, nie tylko dodaną, jest wykreowanie w świadomości odwiedzających marki, jaką jest Akwileja, i umocnienie „pierwszomarkowego produktu” w regionie, to jest Wenecji, która znajduje się w odległości 120 kilometrów.

\title{
WYSTAWA MADE IN ROMA AND AQUILEIA
}

\section{Streszczenie}

Zainaugurowana w sobotę 11 lutego 2017 roku w pałacu Meizlik w Akwilei wystawa jest wydarzeniem kulturalnym mającym istotny aspekt naukowy i popularyzujący badania historyczne. Stanowi ona dokumentację i popularyzację wysiłku badawczego archeologów i historyków, ale i wskazuje na obszary jeszcze mało znane i oczekujące na swoich odkrywców w przeszłości odległej, jak i całkiem bliskiej. Z pewnością wartością jest wykreowanie w świadomości odwiedzających marki, jaką jest Akwileja, i umocnienie „pierwszomarkowego produktu” w regionie, to jest Wenecji, która znajduje się w odległości 120 kilometrów.

Słowa kluczowe: Akwileja, wystawa, starożytność, wyroby, handel

\section{EXHIBITION MADE IN ROMA AND AQUILEIA}

\begin{abstract}
Summary
Inaugurated on Saturday, February 11, 2017 at the Meizlik Palace in Aquileia, the exhibition is a cultural event that has a significant scientific aspect and popularized historical research. It documents and popularizes the research effort of archaeologists and historians, but also points to areas still unknown and awaiting their explorers in the distant past and in the near future. Certainly worth not only being added is the creation of brand awareness in the mind of the visitor and the strengthening of the "first product" in the region, ie Venice, which is located at a distance of $120 \mathrm{~km}$.
\end{abstract}

Keywords: Aquileia, exhibition, antiquity, wares, trade 